\title{
A Proposed Investment on a University Campus
}

\author{
Mohammed H. S. Al Ashry (Ashry) ${ }^{1}$ \\ ${ }^{1}$ Department of Computer Science, the Community College; Department of Computer Science, the College of \\ Sciences and Literature, Shaqra University, Shaqra, Saudi Arabia \\ Correspondence: Mohammed H. S. Al Ashry (Ashry), Department of Computer Science, the Community College; \\ Department of Computer Science, the College of Sciences and Literature, Shaqra University, Shaqra, Saudi Arabia. \\ Tel: 966-55-990-0033.
}

Received: May 17, 2017

Accepted: August 2, 2017

Online Published: October 17, 2017

doi:10.5430/ijfr.v8n4p213

URL: https://doi.org/10.5430/ijfr.v8n4p213

\begin{abstract}
College days are probably the most memorable years of a man or woman's life. The students' unions' associations and entertainment building usually houses rooms for meetings and seminars, a book store, a small grocery store, a novelty store, a number of brand name fast and regular food restaurants, an arcade for games machines, bowling, ping pong, billiards, and a large space with appropriate seating for students and guests, and large screen TV's and a movies theater. This paper proposes a scheme to build a risk managed students association building dedicated to the satisfaction of campus' students' and visitors' needs. The return on its operations is assumed to be very rewarding to entrepreneurs and small businesses alike. This paper presents a case in which a union building is budgeted, three legal businesses leasing spaces within this building. The building's budgeted capital is financed. The space leased by the three businesses represents a small percentage of the overall structure, however, its revenue and specifically input into the building's investment is relatively much larger, emphasizing that the union's building's investment is a successful venture. An element of humorous sarcasm is introduced in describing one of the union building's leasing businesses; a provision of an entertaining flavor to escort readers' attention.
\end{abstract}

Keywords: present value p: initial investment, future value F: future revenue, interest i: loan cost percentage, annual payment A: the loan annual payment, time series: the period in years for the financed loan's repayment

\section{Literature Review}

This paper presents a scheme for the establishment of a students' union building on universities' campuses. There are no academic papers on this subject from a business perspective; although the social aspects of universities campuses, in general, have been investigated and explored. The importance of the subject stems from its importance to the students in terms of entertainment and other aspects of social services.

Businesses have always rushed into opportunities on universities' campuses. However, very limited amount of literature was published in terms of the social and entertainment attributes. Businesses perception of such opportunities centers on the rental aspects of such projects, limiting the prospect of the building's essential value to a small number of customers, contractors, instead of a large number of consumers, students. This has always been the theme of the literature related to projects and businesses investing in building structures on universities' grounds. Large restaurant franchises, mom and pap stores are the main investors when dealing directly with students through renting small spaces in such buildings to accommodate students' needs. Literature related to universities focused on so called knowledge economy and its influence on education, campus sustainability, and the management of campus buildings and facilities. The actual building of an infrastructure related literature that serves the students in terms of their education and entertainment is almost null; academically speaking. This paper focuses on the specifics of the students' sustenance and entertainment needs.

\section{Introduction}

Students' association (union) buildings are the corner stone of students' life on campus. Its existence is necessary for a lot of the daily students' activities. Some students enjoy doing their homework in one of the building's coffee shops. Some spend many of their daily hours between lectures, either working in one of the businesses in the building and or enjoying their leisure time with friends. Some campus housing students do all their shopping for clothing, grocery and more in the little stores located within this building. 
Students' residing within university campus and its peripherals meet in restaurants and cafés to study, get to know each other and so forth. Having a place within the campus area facilitates such activity in distance and time. A union building is a facility that encompasses rooms where students' services such as athletic units, intellectual and political groups meet and or hold their activities, respectively and more. Most often, universities catering services are located within such buildings. Foundations built to provide trust funds and scholarly grants are often located in these buildings.

Establishing such facility as an investment is certain to succeed. The most important element in the success of an investment is the availability of dedicated customers and consumers. Restaurants and cafés meet students' needs for food and study space, respectively. Entertainment centers satisfy students with desire to play games, watch movies and more.

A lot of students spend their weekend nights pleasuring themselves in the game rooms playing billiards, the arcade machines, or just bowling. Many student-groups meet in this building to discuss research, exchange ideas or prepare for an exam. The availability of food places, coffee shops and seating space large screen TV's attract students to the building. The larger the school attendants the larger number of visitors and customers. The students association building in any university is a good business venture. Most universities locate their catering services in the upper deck of the union buildings.

\section{Analysis}

Forecasting the future value of an investment provides ample data on the investment, subject to quality and availability of related information. The return on an investment is calculated using return on operations of the businesses leasing the building's units. The cost of constructing the building can be the present value investment for a single or group of investors. The future value of this investment, assuming the building units are leased by the main building investors, is the total revenue, of all the leased units, over the estimating time series minus maintenance cost. The return on the investment is the future value minus the cost of the construction, plus the return on the units' leases of the periods beyond the cost estimating time series. Assuming investors utilize the space for their own ventures, cost of leases will be an added cost for the space used; otherwise, the investment's revenue is just the total value of the units' lease over the period of the time series, beyond that is pure profit. I postulate that the project is profitable, for investors, either through leasing the space or utilizing space for their own ventures. I also postulate that the revenue is subject to cost, more spending means more revenue.

Forecasting the future value of an investment requires determining the cost of the project and estimating revenue that covers the project's cost and the entailing interest, over a certain period of time. Let us assume that the cost of the project is SR10.50 million. Let us also assume that the entire SR10.5 \$2.8 million, was borrowed with a 5\% interest over 10 years. The investment must bring revenue to pay off the loan with profits well over the 5\% interest. It is assumed that loan payments start after construction ends, or when it is ready for leasing. Utilizing the future value math, equation 1 , we can calculate the cost of the investment to be as follows:

The future value:

$$
\mathbf{F}_{\mathrm{i}}(\mathrm{t})=\mathbf{P}_{\mathrm{i}}(\mathrm{t})\left(1+\mathrm{r}_{\mathrm{i}}\right)^{\mathrm{t}}
$$

Where r: is the interest rate,

$\underline{\mathrm{t}}$ : is the period in years,

P: is the present value of the investment, and

i: the components of the investment to be evaluated over time

The cost of construction is measured in capital per square meter, subject to floor, services, amenities and safety features. The lot's area is assumed to be slightly over $4000 \mathrm{~m}^{2}$. In this case, if the interest is based on annual basis, $\mathrm{i}=$ $0 \ldots \mathrm{n}$, for cost of components in the building's investment worksheet; $\mathrm{t}=1 \ldots 10, \mathrm{r}=5 \%$, and $\mathrm{P}=\mathrm{SR} 10.5$ million. The university may construct the building and lease it to investors, or lease the lot to bidding investors to build it and run it with a percentage of the profits in the contract's clause for the university. The future value of the investment $\mathrm{F}_{\mathrm{i}}(\mathrm{t})=10500000 *(1+0.05)^{10}=17103393.6$ (Saudi Riyals, SR). The investor's annual payment A, for the next ten years, can be calculated using the following equation:

$$
\mathrm{A}=(\mathrm{Fi}) /\left((1+\mathrm{i})^{10}-1\right)
$$

We find $\mathrm{A}=855169.7 /(0.629)=1359798(\mathrm{SR})$. The investor(s) have to earn, on annual basis, more than the annual payment on their investment loan. The investment must generate revenue well over the calculated future value, to be 
considered a successful venture. Now let us assume that the building is made up of three floors, including a basement. Let us also assume the building houses space for ten restaurants of various sizes, spread over the basement and ground floor. A couple of partitions for a general small retailer and or a novelty store. A wide space for a set of game rooms, bowling alley, an arcade, a couple of coffee shops, space for students to sit, study, watch some entertainment located on both the basement and ground floor. A movie theater located in the basement, covering the ground floor above, for nightly and weekend operations, and or according to the university regulations. A number of rooms and a lecture theater on the first floor for the students' union meetings and offices that can be utilized by the university and the students' association.

The above spaces can be leased to the university, other businesses, and the students' union's association. It is common that such projects encompass the basics, electric outlets, toilettes and washing rooms in preset locations, safety features and so on, however, leasing businesses are expected to add their own where necessary. Following section will delve into the process of managing the investment and providing examples of some businesses leasing spaces, such as restaurants, and or stores.

\section{The Approach}

Investing in real-estate, especially construction can be a risky venture due to overpriced viable real estate, competition and costly maintenance. Investing within university's campuses is almost guaranteed success, due to the constant and consistent availability and close proximity of consumers; students, faculty members and visitors. Few universities allow for ownership of on-campus lots, however, leasing and or investing in businesses within the campus property is encouraged. Profits are the driving force behind any investment. All businesses leasing partitions within university campus properties will be seeking large profits. Assuming an investor decides to establish a restaurant within the campus, fast food should be at the top of the list. Fast food takes less time to prepare and easy to take out. Students, in most cases, are on the run for lectures' schedules and other duties.

Most investors worry about the competition, long term viability and benefits, and last but not least profit. Competition, for providing students' services is speculative however only one students' union building is allowed in any university. Campuses are always busy with students and visitors; their desire to meet and eat within the peripheral of the school is favorable. Thousands of students roam the campus grounds on daily basis.

This paper presents three of the businesses leasing in the union's building. Taco Bell franchise was the first fast food restaurant to lease one of the spaces dedicated for restaurants. Its food, although ethnic, is popular. The following is its financial cash outflow sheet. The Taco Bell franchise's restaurant branch is one of the established ventures, and paid/spent SR14700 per month leasing one of the spaces designated for restaurants. The lot rent, SR10000, plus SR5414 for Taco Bell's added structure and maintenance minus SR714 for structural depreciation, on a one year contract extendable to ten years. The restaurant's initial worksheet, cost, cash outflow, provides us with ample data on its future balance sheet and income statement.

Table 1 provides us with the cost estimate of the Taco Bell on monthly, annual and ten years bases. The secured capital was predictably long term loan with $5 \%$ annual interest. The restaurant's structure, tools, instruments, cooking material, packaging, ingredients and other services are estimated using wholesale values. Employees' pay is based on the relative cost of living and income in Saudi Arabia where it fluctuates, subject to provincial residence and distance from the metropolitan areas (1). The loan is assessed on the basis of the appraised monthly wholesale prices and one year is just a multiple of that, and so are the ten years estimates. So, the prices of supplies and other related items and articles may fluctuate over time, but within acceptable average. Table 1 is based on initial cash outflow, where the borrowed money is the inflow - initial income, and the net income is nil, since the restaurant is in the presale stage. To make sure the evaluation is correct, the expenditure is taken out of the borrowed money as a percentage, to keep track of the cost and guarantee accuracy. Every item on the monthly list is equally listed proportionally on the annual and ten yeas' lists using excel functions.

The first year's expense estimates reaches over one million and three hundred thousand Saudi Riyals. Now, the sales for that year are expected to exceed that value. The ten years expenditure estimate is over thirteen million Saudi Riyals. The total estimated cost of the entire union building borrowed and paid off over ten years is a little over seventeen million Saudi Riyals. The lease contract for the Taco Bell restaurant only, over ten years, exceeds one million and seven hundred thousand Saudi Riyals. The building investors are likely to earn net profit and pay off their loan earlier than anticipated. The life cycle of a concrete structure, with proper maintenance, may exceed one hundred years. The investors, considering the type of university land lease contract, size of real estate taxes and fees, will be making loan free net profits for decades afterwards. 
Table 1. The Taco Bell business worksheet (Note 1)

\begin{tabular}{|c|c|c|c|c|}
\hline Period $\rightarrow$ & Monthly & $\%$ of the monthly & Annually & Over 10 Years \\
\hline Activity $\downarrow$ & $P_{i}(t)$ & $1 / \operatorname{Pi}(\mathrm{t})$ & 12 months & Ten years cost \\
\hline Budgeted cost & 109282 & $100 \%$ & 1311384 & 13113840 \\
\hline Basic food & 12000 & 10.98076536 & 144000 & 1440000 \\
\hline Waste & 500 & 0.45753189 & 6000 & 60000 \\
\hline Raw waste & 600 & 0.549038268 & 7200 & 72000 \\
\hline Employee meals & 1600 & 1.464102048 & 19200 & 192000 \\
\hline Condiments spices & 2500 & 2.28765945 & 30000 & 300000 \\
\hline Ovens, frigerator, related Instroments & 2000 & 1.83012756 & & 240000 \\
\hline Paper material & 1000 & 0.91506378 & 12000 & 120000 \\
\hline Plastic material & 1000 & 0.91506378 & 12000 & 120000 \\
\hline Computer, screens, software & 1500 & 1.37259567 & 18000 & 180000 \\
\hline Royalty fees & 5000 & 4.5753189 & 60000 & 600000 \\
\hline \multirow[t]{2}{*}{ Total direct cost } & 27700 & 25.3472667 & 332400 & 3324000 \\
\hline & & & & 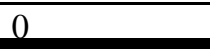 \\
\hline \multirow[t]{2}{*}{ Total cost - direct cost } & $\$ 81.582$ & 74.6527333 & 978984 & 9789840 \\
\hline & & & & 0 \\
\hline Uniforms & 417 & 0.381581596 & 5004 & 50040 \\
\hline Transportation & 2500 & 2.28765945 & 30000 & 300000 \\
\hline Maintenance/repair & 1000 & 0.91506378 & 12000 & 120000 \\
\hline Cleaning supplies & 1000 & 0.91506378 & 12000 & 120000 \\
\hline Office expense & 150 & 0.137259567 & 1800 & 18000 \\
\hline Labor cost (salary/bonus) & 30000 & 27.4519134 & 360000 & 3600000 \\
\hline Managers & 8000 & 7.32051024 & 96000 & 960000 \\
\hline Home delivery expense & 2000 & 1.83012756 & 24000 & 240000 \\
\hline Utilities & 2200 & 2.013140316 & 26400 & 264000 \\
\hline Miscellaneous & 1000 & 0.91506378 & 12000 & 120000 \\
\hline Medical insurance & 2000 & 1.83012756 & 24000 & 240000 \\
\hline Telephone & 500 & 0.45753189 & 6000 & 60000 \\
\hline Stationary & 100 & 0.091506378 & 1200 & 12000 \\
\hline \multirow[t]{2}{*}{ Total fixed cost } & 50867 & 46.54654929 & 610404 & 6104040 \\
\hline & & & & 0 \\
\hline Total cost - direct and fixed costs & $\$ 30.715$ & 28.106184 & 368580 & 3685800 \\
\hline Computer \& related & 551 & 0.504200143 & 6612 & 66120 \\
\hline All cooking \& storage related & 536 & 0.490474186 & 6432 & 64320 \\
\hline Structural & 714 & 0.653355539 & 8568 & 85680 \\
\hline \multirow[t]{2}{*}{ Total depreciation } & 1801 & 1.648029868 & 21612 & 216120 \\
\hline & & & & 0 \\
\hline TM building structure & 5414 & 4.954155305 & 64968 & 649680 \\
\hline Marketing & 5000 & 4.5753189 & 60000 & 600000 \\
\hline Admin & 3000 & 2.74519134 & 36000 & 360000 \\
\hline Lot rent & 10000 & 9.150637799 & 120000 & 1200000 \\
\hline Employee benefits & 3500 & 3.20272323 & 42000 & 420000 \\
\hline Staff accommodation & 2000 & 1.83012756 & 24000 & 240000 \\
\hline
\end{tabular}




\begin{tabular}{lllll}
\hline Total indirect cost/overhead & 28914 & 26.45815413 & 346968 & 3469680 \\
\hline Total Cost & 109282 & 100 & 1311384 & 13113840 \\
\hline \hline & & & & \\
\hline \hline Cost overrun & 0 & 0 & 0 & 0 \\
\hline
\end{tabular}

Tables 2 and 3 are on the novelty store business, in one of the stores' partitions, leased by a gentleman named Houdini (Note 2) (5). This store sells articles, costumes, and some magic items, plus other material students might utilize in classes and daily life. The name Houdini is well known for tricks one of which may have killed him, and so the name's fame is basically an ad of its own for this rare quality store. Table 2 is an income statement. The statement displays Houdini's weekly income statement. Since the store is one of few available novelty stores in the entire city, it is utilized by parents in preparing their kids' birthday parties with magical trickeries, fantasy displays and entertainment. The store is very popular throughout the city and gets a lot of orders for appearances on valentine day, birthdays, new-year's day, and on many other special occasions. The lot rent for Houdini's novelty store is greater than that of the Taco Bell, although it was less likely to be as successful.

Table 2. The weekly income statement

\begin{tabular}{|c|c|c|}
\hline Activity & Magnitude & Explanation \\
\hline Revenue & 1500 & Novelty sales \\
\hline \multirow{3}{*}{ Total } & 20350 & Appearances \\
\hline & 1350 & Owed for novelty sales (accounts receivable) \\
\hline & 23200 & Total sales \\
\hline \multirow[t]{2}{*}{ Cost of service } & 1000 & Payment for novelties \\
\hline & 100 & Late payment (accounts payable) \\
\hline \multirow{2}{*}{ Total } & -50 & Inventory (unsold stock) \\
\hline & 1050 & Total cost of services rendered (direct cost) \\
\hline Gross profit & 22150 & Total profit after direct cost \\
\hline \multirow[t]{6}{*}{ Expense } & 1300 & Wages including 100 late payment \\
\hline & 1450 & Total travel expense 1500 less 50 prepaid travel \\
\hline & 280 & Total rabbit and rabbit feed 330 less 50 recovered losses \\
\hline & 110 & Cleaning cost \\
\hline & 940 & Total costume and magic books depreciation \\
\hline & 4000 & Lot rent \\
\hline Total & 8080 & Total expenses \\
\hline Net profit & 14070 & Total net earnings \\
\hline
\end{tabular}

Table 3 is Houdini's balance sheet. Three important data is provided in the balance sheet: assets, liabilities, and equities. Lower liability businesses indicate good financial status, and Houdini's has a very low liability. Greater equity on the other hand indicates stronger ownership and greater selling value with higher ranking for franchising, and open market candidacy. 
Table 3. The weekly balance sheet

\begin{tabular}{|c|c|c|}
\hline activity & Magnitude & Explanation \\
\hline \multirow[t]{6}{*}{ Current assets } & 460 & Cash \\
\hline & 120 & Bank \\
\hline & 350 & Accounts receivable \\
\hline & 50 & Inventory \\
\hline & 50 & Prepaid expense \\
\hline & 1030 & Total current assets \\
\hline Total & 1030 & \\
\hline \multirow[t]{5}{*}{ Long term assets } & 200 & Playing cards \\
\hline & 1000 & Magic books and equipment \\
\hline & 1500 & Costumes \\
\hline & 2500 & Disappearing lady's act \\
\hline & -940 & Depreciation \\
\hline Total & 4260 & \\
\hline Net assets & 5290 & \\
\hline \multirow[t]{2}{*}{ Liabilities } & 100 & Novelties (accounts payable) \\
\hline & 100 & Wages (accounts payable) \\
\hline Total & 200 & \\
\hline \multirow[t]{3}{*}{ Equity } & 2500 & Costumes - magic books and equipment paid for from \\
\hline & 15 & Prepaid travel expense paid for from owner's savings \\
\hline & 14070 & Owner's net profit \\
\hline Total Liabilities \& Equity & 16785 & Total liabilities and equities \\
\hline Owner's drawing & 11495 & Less owner's spending \\
\hline Net liability \& equity & 5290 & \\
\hline
\end{tabular}

Houdini's balance sheet also has less good news for investors, with its high long term assets and low current assets. Long term assets may depreciate and are liable at some point; current assets, on the other hand, can be turned to equities depending on its type. Material current assets can become a liability if and when asset debt is due.

The Houdini's business, however, will pay SR16000, which can accumulate to SR1920000. This is SR200000 more than the Taco Bell's total rent amount. The two businesses already account for more than $20 \%$ of the total loan owed by the students' union's building owners, over the loan period.

Figure IV is a copy of a business found everywhere in the world, used cars rental businesses. The word used car, is a liability of its-own. Used cars salesmen are among the least trusted people in the world, especially in the USA; it is believed that almost all used cars salesmen are on the FBI list. Werdan's Used Cars Rental leased one of the partitions designated for stores (Note 3). Here is the story of Werdan's business, so called "Werdan's Used Cars Rental" (WUCR). It used to be called (RSTC), the Road Scoundrels Taxi Company, and was established on the $15^{\text {th }}$ of January of 2008 by a businessman named Werdan, who was known as Werdan the crook. In order to start his business he leased three Repossessed cars for 10000 SR each (in which he utilized bribery to get the deal) for a period of three years paid 20000 SR cash and the rest to be paid in equal instalments over the next three years (with $10 \%$ annual interest). He also hired three unemployed drivers with ethically questionable reputation (to be paid 1000 SR each per month plus $\sim 3-4 \%$ of the net profit as commission). He also hired a caretaker and an accountant, ( two months later) both of whom were just released from the Riyadh county jail, one for armed robbery, the other for fraudulent activities (also to be paid $1000 \mathrm{SR}$ each per month, with commission).He leased (for three years) an office space on the corner of a gas station (known for its unusually high-priced gasoline the quality of which is at best suspect); including the abused furniture and other living amenities the lease would cost $25 \mathrm{k}$ SR of which he paid $10000 \mathrm{SR}$ cash and the rest to be paid in equal instalments over the next three years (with $10 \%$ annual interest). During the first two weeks (last two weeks of 
January) the taxicabs collectively incurred 7000 SR from its customers and victims, and sustained 1500 SR in losses resulting from traffic tickets and cost of customers' medical emergencies/injuries, inflicted by the drivers. The loss was paid at the end of that month. The business transactions of the Road Scoundrels for the first year ending on the $31^{\text {st }}$ of December are provided in the following Table 4.

Table 4. Werdan's worksheet of (RSTC)

\section{Long term assets still owned by the end of the first year} SR

Three cars at total cost 32063

Office space at total cost 28095

Cars insurance (covering liabilities only) at cost 4500

Medical insurance for employees and drivers at cost 2500

Phone service contract including HF mobile broadcasting system 3000

\section{Amounts received (cash and cheques)}

\begin{tabular}{|c|c|}
\hline Cabs fees & 197500 \\
\hline Taxicabs contracts & 35000 \\
\hline Special deliveries & 18000 \\
\hline \multicolumn{2}{|l|}{ Amounts paid (cash and cheques) } \\
\hline Drivers Wages & 34500 \\
\hline Other employees wages & 18500 \\
\hline Cars maintenance & 1500 \\
\hline Commissions $(\sim 3.9 \%)$ & 6900 \\
\hline Gasoline & 1800 \\
\hline Medicine & 500 \\
\hline Cleaning and care taking stuff & 1200 \\
\hline Gratuities (Werdan shared gratuities by $50 \%$ ) & 4000 \\
\hline Werdan's drawings from his business (including his 5000 SR monthly salary) & 80000 \\
\hline Werdan paid cash to purchase a car for his personal use for & 64650 \\
\hline \multicolumn{2}{|l|}{ Other information } \\
\hline Invoices received from gasoline provides & 1900 \\
\hline Invoices received from car workshops & 1800 \\
\hline Contracts bank balance & 18000 \\
\hline Special deliveries bank balance & 12000 \\
\hline Cab fees bank balance & 500 \\
\hline Soft drinks and soda pops inventory (for guests and customers) & 500 \\
\hline
\end{tabular}

\begin{tabular}{ll}
\hline \hline Notes & 5000 \\
\hline \hline Werdan paid in advance for the following month of January & 3000 \\
\hline Werdan is owed for special deliveries for which he was paid with deferred cheques (to January) & 4000 \\
\hline The cars (total value) depreciated on annual bases & 300 \\
\hline The office space furniture and other equipment collectively depreciated at & 350 \\
\hline The cars and medical insurance had an inflationary rate appreciating its value by 5\% for an annual total of & 1000 \\
\hline Werdan wrote off an income as a loss after the death of a contracted customer & 30
\end{tabular}


Table 5, provides us with the cost and profit of Werdan's new business leasing within the students' union's building. Its monthly revenue, unlike his previous business, is astoundingly high, with great profit.

Table 5. Werdan's income statement

\begin{tabular}{lll}
\hline Revenue & Magnitude & Explanation \\
\hline Taxicab fees & 197500 & Total monthly Regular cab fares \\
\cline { 2 - 3 } Cab contracts & 35000 & Income from monthly or weekly contracts \\
\cline { 2 - 3 } Cab special deliveries & 18000 & Special trips/ short term contracts \\
\cline { 2 - 3 } Owed for contracts & 3000 & Accounts receivable (the customers owe Werdan) \\
\hline Total & 253500 & \\
\hline
\end{tabular}

\begin{tabular}{|c|c|c|}
\hline \multicolumn{3}{|l|}{ Direct cost } \\
\hline Driver's wages & 34500 & Drivers are a product labor cost \\
\hline Auto maintenance & 1500 & \\
\hline Auto maintenance & 300 & Accounts payable payment \\
\hline Gas & 1800 & \\
\hline Gas & 100 & Accounts payable payment \\
\hline $\begin{array}{l}\text { Inventory (deducted) } \\
\text { Inved }\end{array}$ & -500 & Unused Inventory \\
\hline Total & 37700 & \\
\hline Gross profit & 215800 & \\
\hline Operating expense & & \\
\hline Wages & 18500 & Non driver's wages \\
\hline Commissions & 6900 & Commissions taken from net profit \\
\hline Medicine & 500 & Expense for dispensable/ disposable medicine \\
\hline Cleaning & 1300 & \\
\hline Gratuity & 4000 & In Arabic (Baksheesh) \\
\hline Prepaid wages & 5000 & \\
\hline Depreciation (auto) & 4000 & \\
\hline Depreciation (office) & 300 & \\
\hline Income write offs & 1000 & The death of a customer before authorizing payment \\
\hline Total & 37500 & \\
\hline Net profit & 178300 & Explanation \\
\hline
\end{tabular}

It provides detail data on the company's main sources of income, revenue, costs of his drivers, maintenance and fuel. Ample data on his expenses allows for accurate explanation of his net profit. There is also explanation to some of the vague items in the statement offering confidence in the data.

Table 6, unlike the data on Table 4 provides us with better data on Werdan's business with a detailed balance sheet. His attempt to become a legitimate businessman is paying off. His business's assets, liabilities, and equities are well defined indicating readiness for a meticulous audit. An observation worth mentioning is his reasonably high current assets, which can be a plus however, his high long term assets are too high which could spell a disaster if at some point they turn into a liability. 
Werdan's liabilities are, however, reasonably low, compared to his assets, which is another plus. One thing that may bring a smile to Werdan's face is his high equity value. This can be his greatest selling point for either attracting investors, or to just selling the business to the highest bidder.

The werdan's business revenue and net profit justifies the assumption that investing in any of the businesses within the university's students' union building is a valid proposition. The following section will delve into proving the validity of this construction business scheme by utilizing the cash flow, revenue, relationship to the outflow, the cost and their intertwining predictability. The variance and deviations in the respected relationship will be used to prove that the error in the assumption is low enough suggesting such validity.

Table 6. The balance sheet of the New Werdan's Used Cars Rentals (WUCR)

\begin{tabular}{|c|c|c|}
\hline Current assets & Magnitude & Explanation \\
\hline Contract bank balance & 18000 & The accounts balance at period's end \\
\hline Special delivery bank balance & 12000 & The accounts balance at period's end \\
\hline \multirow{2}{*}{ Taxicab fees bank balance } & 500 & The accounts balance at period's end \\
\hline & 5000 & The employees (including drivers) wages \\
\hline \multirow{2}{*}{$\begin{array}{l}\text { Prepaid expense } \\
\text { Accounts receivable }\end{array}$} & 3000 & Money owed to Werdan \\
\hline & -1000 & Un credited accounts receivable check \\
\hline A.C. doubtful accounts & 500 & Un used inventory \\
\hline
\end{tabular}

Inventory

\begin{tabular}{|c|c|c|}
\hline Total current assets & 38000 & \\
\hline \multicolumn{3}{|l|}{ Long term assets } \\
\hline Cost of automobiles & 32063 & Cost of the cars including the accrued debt \\
\hline Office space & 28095 & Cost of the office space including the accrued debt \\
\hline Auto insurance & 4500 & Insurance Over three years \\
\hline \multirow{3}{*}{$\begin{array}{l}\text { Medical insurance } \\
\text { HF communication system }\end{array}$} & 2500 & Insurance Over three years \\
\hline & 3000 & Broad band mobile communication system \\
\hline & -4000 & Annual Auto depreciation \\
\hline Auto depreciation & -300 & Annual furniture depreciation \\
\hline Furniture depreciation & 350 & The prepaid three years insurance appreciated as insurance in \\
\hline Auto and medical insurance & & Saudi Arabia decreased \\
\hline Total long term assets & 66208 & \\
\hline Total assets & 104208 & \\
\hline
\end{tabular}

\begin{tabular}{lll}
\hline Liabilities & \\
\hline Current & \multicolumn{2}{l}{} \\
\hline Accounts payable (gas) & 100 & Gas debt \\
\cline { 2 - 3 } Accounts payable (maintenance) & 300 & Maintenance debt \\
\cline { 2 - 3 } Current maturity (auto) & 4021 & The auto's long term debt annual maturity is due \\
\cline { 2 - 3 } Current maturity (office) & 6031.7 & The office's long term debt annual maturity is due \\
\hline Total current liabilities & 10452.7 & \\
\hline Long term liabilities (debt) & & \\
\hline Auto & 8042 & Auto long term debt including accrual \\
Office & 12063.3 & Office long term debt including accrual \\
\hline Total long term debt & 20105.3 & \\
\hline Total liabilities & 30558 & \\
\hline
\end{tabular}




\begin{tabular}{llll}
\hline Equity & & & \\
\hline Owner's capital (fund) & 40000 & I call it Long term equity (can be used as an equity line to \\
\hline \multicolumn{1}{c}{$\begin{array}{l}\text { Net profit } \\
\text { Werdan Drawings }\end{array}$} & $\begin{array}{l}+178300 \\
\text { Retained earnings }\end{array}$ & 33650 & $\begin{array}{l}\text { The earnings retained after all expenses/taxes and dividend are } \\
\text { paid (in this case it includes an unused amount of inventory) }\end{array}$ \\
Total equity & & \\
\hline \multicolumn{3}{l}{73650} & \\
\hline Total equity and liabilities & 104208 & \\
\hline
\end{tabular}

\section{The Methodology}

In this paper, it is assumed that the average cash flow, revenue, of Taco Bell in Arabia has a direct proportional relationship to the outflow, cost. In order to do an analysis of the cash flow of Taco Bell restaurant and its relationship to the cost we have to first calculate the average cash flow of a Taco Bell in Saudi Arabia. Due to lack of financial data on Taco Bell in Saudi Arabia, data from the US franchise on average revenue is employed in combination with approximated sales values in Saudi Arabia. The number of open Taco Bell restaurants in Saudi Arabia, three, is much smaller than its counterpart in the US, by population ratio. Although it is considered as popular if not more than in the US, consequently, we assume the data used is acceptable for our purpose. Table 7 houses actual prices of the most popular Taco Bell's menu items, and hypothetical data on Taco Bell's sales, based on data provided by employees of the restaurant in Riyadh Saudi Arabia. Of course, the data was averaged along with data from YUM's (the owner of Taco Bell) website (Note 4); as in Table 8 (Note 5), to produce the data in the Table 10 (3).

Table 7. The price estimates per Taco Bell store in Saudi Arabia

\begin{tabular}{llllllll}
\hline Item & $\begin{array}{l}\text { Crunchy } \\
\text { taco }\end{array}$ & $\begin{array}{l}\text { Soft } \\
\text { taco }\end{array}$ & Burrito & Scrambler & Nacho & Combos & Total \\
\hline Price Saudi Riyals (SR) & 4 & 5 & 10 & 8 & 5 & 20 & 52 \\
\hline $\begin{array}{l}\text { Number sold (daily) } \\
\text { approximated }\end{array}$ & 400 & 400 & 300 & 100 & 300 & 500 & 2000 \\
\hline $\begin{array}{l}\text { Total price (SR) (Note 6) } \\
\text { (daily) }\end{array}$ & 1600 & 2000 & 3000 & 800 & 1500 & 10000 & 18900 \\
\hline
\end{tabular}

There are six popular items on the Taco Bell's menu: Burritos, Scramblers, Nachos, soft and Crunchy tacos, Chalupas and their combos, which include combinations of the above plus a drink and fries. To simplify the calculation we choose one average price for the combo meals, and the single prices for the rest of the main six menu items.

Table 8. Taco Bell data, from the US, Saudi Arabia, and the average for this paper

\begin{tabular}{cccccccc}
\hline Annual Revenue $\mid$ Dates & 11 & 12 & 13 & 14 & 15 & 16 & \\
\hline The averages Revenue (The Paper in millions of \$) & 1.32 & 1.39 & 1.46 & 1.53 & 1.60 & 1.68 & 0.05 \\
\hline Sales (millions of \$) & 1.12 & 1.18 & 1.24 & 1.30 & 1.36 & 1.43 & 0.05 \\
\hline Total cost of the product (millions of \$) & 1.11 & 1.17 & 1.23 & 1.29 & 1.35 & 1.42 & 0.05 \\
\hline Operating profit (millions of \$) & 0.21 & 0.22 & 0.23 & 0.24 & 0.25 & 0.26 & 0.04 \\
\hline
\end{tabular}

Table 7 provides the average price per meal for the combos and single items, plus the total daily sales. These prices are subject to size and ingredients. Before moving ahead, it is proper to mention that the Table 9 provides us with a correction to the Taco Bell's worksheet of 2011, which employs the Saudi Riyal (4). The owed difference for the 
first month is borrowed from the following months, where the values are based on a new budgeting plan that takes into account that the difference is spread evenly over the last eleven months of the year (6).

Table 8 (Note 7) provides the US and Saudi total Taco Bell's revenue, sales, total cost and profit in US dollars. The last column is the extrapolation factor/coefficient. The average of the US extrapolated and Saudi approximated data are employed.

Table 9. The Taco Bell business worksheet

\begin{tabular}{|c|c|c|c|c|}
\hline Period $\rightarrow$ & Monthly & $\begin{array}{l}\% \text { of the } \\
\text { monthly }\end{array}$ & Annually & $\begin{array}{c}\text { Over } 10 \\
\text { Years }\end{array}$ \\
\hline Activity $\downarrow$ & $\mathrm{P}_{\mathrm{i}}(\mathrm{t})$ & 1/ $\mathrm{Pi}(\mathrm{t})$ & 12 months & $\begin{array}{c}\text { Ten years } \\
\text { cost }\end{array}$ \\
\hline Budgeted cost & 168294.28 & $100 \%$ & 2019531.36 & 20195313.6 \\
\hline Basic food & 20000 & 11.88 & 240000 & 2400000 \\
\hline Waste & 700 & 0.42 & 8400 & 84000 \\
\hline Raw waste & 800 & 0.48 & 9600 & 96000 \\
\hline Employee meals & 1600 & 0.95 & 19200 & 192000 \\
\hline Condiments spices & 3850 & 2.29 & 46200 & 462000 \\
\hline $\begin{array}{l}\text { Ovens, frigerator, related } \\
\text { Instroments }\end{array}$ & 2000 & 1.19 & & 240000 \\
\hline Paper material & 1540 & 0.92 & 18480 & 184800 \\
\hline Plastic material & 1540 & 0.92 & 18480 & 184800 \\
\hline Computer, screens, software & 1500 & 0.89 & 18000 & 180000 \\
\hline Royalty fees & 8000 & 4.75 & 96000 & 960000 \\
\hline Total direct cost & 41530 & 24.68 & 498360 & 4983600 \\
\hline Total cost - direct cost & $\$ 126,764$ & 75.32 & 1521171.36 & 15211713.6 \\
\hline Uniforms & 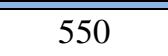 & 0.33 & 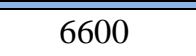 & 266000 \\
\hline Transportation & 4500 & 2.67 & 54000 & 540000 \\
\hline Maintenance/repair & 1000 & 0.59 & 12000 & 120000 \\
\hline Cleaning supplies & 1540 & 0.92 & 18480 & 184800 \\
\hline Office expense & 150 & 0.09 & 1800 & 18000 \\
\hline Labor cost (salary/bonus) & 46200 & 27.45 & 554400 & 5544000 \\
\hline Managers & 12320 & 7.32 & 147840 & 1478400 \\
\hline Home delivery expense & 2000 & 1.19 & 24000 & 240000 \\
\hline Utilities & 4500 & 2.67 & 54000 & 540000 \\
\hline Miscellaneous & 1000 & 0.59 & 12000 & 120000 \\
\hline Medical insurance & 3080 & 1.83 & 36960 & 369600 \\
\hline Telephone & 500 & 0.30 & 6000 & 60000 \\
\hline Stationary & 200 & 0.12 & 2400 & 24000 \\
\hline Total fixed cost & 77540 & 46.07 & 930480 & 9304800 \\
\hline Total cost - direct and fixed costs & $\$ 49,224$ & 29.25 & 590691.36 & 5906913.6 \\
\hline Computer \& related & 770 & 0.46 & 9240 & 92400 \\
\hline
\end{tabular}




\begin{tabular}{ccccc}
\hline All cooking \& storage related & 536 & 0.32 & 6432 & 64320 \\
\hline Structural & 900 & 0.53 & 10800 & 108000 \\
\hline \hline Total depreciation & 2206 & 1.31 & 26472 & 264720 \\
\hline TB building structure & 6500 & 3.86 & 78000 & 780000 \\
\hline Marketing & 8200 & 4.87 & 98400 & 984000 \\
\hline Admin & 5000 & 2.97 & 60000 & 600000 \\
\hline Lot rent & 10000 & 5.94 & 120000 & 1200000 \\
\hline lot fees & 5400 & 0.03 & 64800 & 648000 \\
\hline Employee benefits & 8418.28 & 5.00 & 101019.36 & 1010193.6 \\
\hline Staff accommodation & 3500 & 2.08 & 42000 & 420000 \\
\hline Total indirect cost/overhead & 47018.28 & 27.94 & 564219.36 & 5642193.6 \\
\hline Total Cost & 168294.28 & 100.00 & 2019531.36 & 20195313.6 \\
\hline Cost overrun & 0 & 0.00 & 0 & 0 \\
\hline \hline
\end{tabular}

Now, the average daily sales of the estimated sale prices in Saudi Arabia, and the US are utilized, in Table 8 to produce the nominal present value for the indicated year's revenue $(2015), \mathrm{P}_{\mathrm{i}}=(14003+18900) / 2=(\mathrm{SR} 16451.5=$ $\$ 4387$, daily); producing $\sim \$ 1.6$ million, annually (2). It is worth mentioning that the lease of the Taco Bell's lot, Table 9, has increased significantly due to changes in the cost and to modifications to the actual restaurant structure. Data gleaned from some of the employees in the Riyadh's Taco Bells was helpful. The new lot rent, Table 9, is $\$ 21000$, with 10000 for rent plus 6500 for structural modification, 5400 for fees, minus 900 for depreciation, totaling SR252000 on annual basis, and SR2520000, over the ten years lease, and or loan life span. The lease of a partition, one of ten designated for restaurants, is practically paying close to $10 \%$ of the estimated cost of the annual loan's payment.

The data used in Table 8 (Note 8) includes, for the Taco Bell's US franchise data, the years 2013-2015 and partial data from 2016, from YUM's website, the rest was extrapolated in accordance to growth percentages in previous and following years.

The following equation, multi-variant regression, was used to calculate the predicted revenue $\hat{R}$. Its various variables provide components of the prediction analysis, the intercept $b_{R}$ and the slope, and forecast the slope line $m$, of the predicted values (7). The error, residual, in the equation provides us with the fluctuation about the predicted slope line.

$$
\check{\mathrm{R}}_{\mathrm{i}, \mathrm{t}}=\theta_{\mathrm{i}}+\pi_{\mathrm{i}} \mathrm{R}_{\mathrm{i}, \mathrm{t}-1}+\varepsilon_{\mathrm{i}, \mathrm{t}} \mathrm{i}=1 . . \mathrm{n}
$$

Where:

$\check{\mathrm{R}}_{\mathrm{i}, \mathrm{t}}:$ the mean of the predicted value

$\theta_{\mathrm{i}}$ : the nitial value at intercept

$\pi_{\mathrm{i}}$ : the factoring coefficient of the predictor based on the relationship between the variance and covariance of the two variables

$\mathrm{R}_{\mathrm{i}, \mathrm{t}-1:}$ the predictor of the revenue over time, in this case the cost $\mathrm{C}$

$\varepsilon_{\mathrm{i}, \mathrm{t}}$ : the variation around the predicting graph line of the uknown considered to be an error over time

Looking at the Table 10, we can see that the predicted values are linearly proportional to the known values of $\mathrm{R}$.

Table 10. The Taco Bell basic statistical data

\begin{tabular}{llllllll}
\hline Dates & 2011 & 2012 & 2013 & 2014 & 2015 & 2016 & sum \\
\hline Revenue - R & 1.323356 & 1.39 & 1.46 & 1.53 & 1.6 & 1.676712 & 8.980068 \\
\hline Sales - S & 1.122903 & 1.18 & 1.24 & 1.3 & 1.36 & 1.425806 & 7.62871 \\
\hline
\end{tabular}




\begin{tabular}{llllllll}
\hline Total cost of the product- C & 1.112927 & 1.17 & 1.23 & 1.29 & 1.35 & 1.415854 & 7.56878 \\
\hline Operating profit -- OP & 0.210435 & 0.22 & 0.23 & 0.24 & 0.25 & 0.26087 & 1.411304 \\
\hline $\mathrm{R} 2$ & 1.751272 & 1.9321 & 2.1316 & 2.3409 & 2.56 & 2.811364 & 13.52724 \\
\hline $\mathrm{C} 2$ & 1.238606 & 1.3689 & 1.5129 & 1.6641 & 1.8225 & 2.004642 & 9.611648 \\
\hline $\mathrm{RC}$ & 1.472799 & 1.6263 & 1.7958 & 1.9737 & 2.16 & 2.373979 & 11.40258 \\
\hline The predicted value $=\hat{\mathrm{R}}$ & 1.35229 & 1.40178 & 1.46010 & 1.51843 & 1.57675 & 1.64077 & 8.95012 \\
\hline
\end{tabular}

This indicates dependency of the revenue on the cost, which also indicates that the sales are linearly proportional to the business management's assumption of the popularity of the product. The cost management assumed sales would be comparable to those in the US; it turned out to be a valid assumption.

Table 11. The Taco Bell statistical analysis of the slope of the prediction and its initial value - the intercept

\begin{tabular}{|c|c|c|c|c|c|c|c|}
\hline & 2011 & 2012 & 2013 & 2014 & 2015 & 2016 & sum \\
\hline the covariance $\mathrm{R}$ and $\mathrm{C}$ & 0.01243 & & & & & & \\
\hline the $\mathrm{C}$ variance & 0.01278 & & & & & & \\
\hline the $R$ variance & 0.01739 & & & & & & \\
\hline slope $=\mathrm{m}$ & 0.97210 & 0.97210 & 0.97210 & 0.97210 & 0.97210 & 0.97210 & \\
\hline the initial value - intercept $=b$ & 0.27041 & 0.26442 & 0.26442 & 0.26442 & 0.26442 & 0.26442 & \\
\hline the error, so called Residual -- $\varepsilon i, t$ & -0.02893 & -0.01178 & -0.00010 & 0.01157 & 0.02325 & 0.03594 & 0.02995 \\
\hline The residual $=$ Sres & 0.00084 & 0.00014 & 0.00000 & 0.00013 & 0.00054 & 0.00129 & 0.00294 \\
\hline Std deviation of the residual Sres & 0.01670 & & & & & & \\
\hline Std error of the slope (m) & 0.00740 & & & & & & \\
\hline Std error of the intercept (b) & 0.10433 & & & & & & \\
\hline $\begin{array}{l}\text { t statistics slope-large- indicating } \\
\text { proportionality }\end{array}$ & 131.31730 & & & & & & \\
\hline the error in predicted $\hat{R}$ & 0.00084 & 0.00014 & 0.00000 & 0.00013 & 0.00054 & 0.00129 & 0.00294 \\
\hline total variation in the error & 0.00294 & & & & & & \\
\hline estimated variations in the errors & 0.00074 & & & & & & \\
\hline
\end{tabular}

\section{Results}

Table 11, displays the regression analysis with the statistics, the t-slope test, is quite large indicating that the model used for the analysis is very good and is providing very linearly accurate predicted values for the revenue R. this also tells us that the least squares method for predicted, the revenue, is valid for its very closely predicted values. The total variation of the error, the residual, is almost zero an indication of the very low variability of the predicted revenue in comparison to the cost, again, a proof of accuracy. The error in the slope, the line predicting the revenue, and the error in the intercept, the initial function access value are both very small, actually in comparison to both, the cost, predictor, and the revenue, the predicted.

This study of the Taco Bell indicates that the union's building construction, based on the outcome of Taco Bell is almost guaranteed success (8). The 2015 cumulative profit of the three businesses is about $20 \%$ of the revenue, which is reasonable five years into the ten years life-span of the loan for three of more than fifteen potential businesses. More Significant is the cumulative of the three leases; less than $20 \%$ of the available space, practically covers close to $60 \%$ of the loan's annual payment. The chart in Figure I is a line chart of the relationship between the cost and the revenue, the predictor and the predicted. The linearity of the two lines is an indication of the accuracy of the direct proportionality of the two data sets. Table 12, provides the revenue and lot-lease amounts for the three businesses. The total three businesses' lease-amounts indicate that the cumulative leases, assuming proportionally 
direct relationship, for the entire building will be very profitable. It is important to note that the directly revenue to cost proportional relationship is valid only for the study period of the time series. The period beyond the time series may show a different proportionality due to the fact that the loan's payments are paid off and excluded from the cost.

Table 12. Businesses profits and leases for the year 2015 (\$)

\begin{tabular}{lllll}
\hline Activity / Business $\rightarrow$ & Taco Bell & Werdan & Houdini & Total \\
\hline Revenue & 1600000 & 3042000 & 1113600 & 5755600 \\
\hline Profit & 250000 & 178300 & 675360 & 1103660 \\
\hline Lease costs amount & 252000 & 337140 & 192000 & 781140 \\
\hline
\end{tabular}

\section{Conclusion}

Investing in a business within the union's building in any large school, with emphasis on large, can be very rewarding. Consequently, investing in constructing the union building's itself is more than likely to be very profitable. Businesses within university's grounds flourish as a result of the consuming attitude of the inhabitants of the school's residential areas. I recommend investing in a venture within the perimeters of any large school, and especially a building dedicated to serving students.

Of course, investments in schools' services and facilities encompass the involvement of small mom and pap's stores/restaurants alongside large franchises. Restaurants are amongst the most popular ventures on schools' campuses. Many franchises started within or near schools' properties. Entertainment facilities within a students' union building included a bowling alley, an arcade room, a game room, and or billiard cafés/bars. It is almost always profitable to start a small business within a popular school building. I certainly recommend such ventures with long term financial sustainability's.

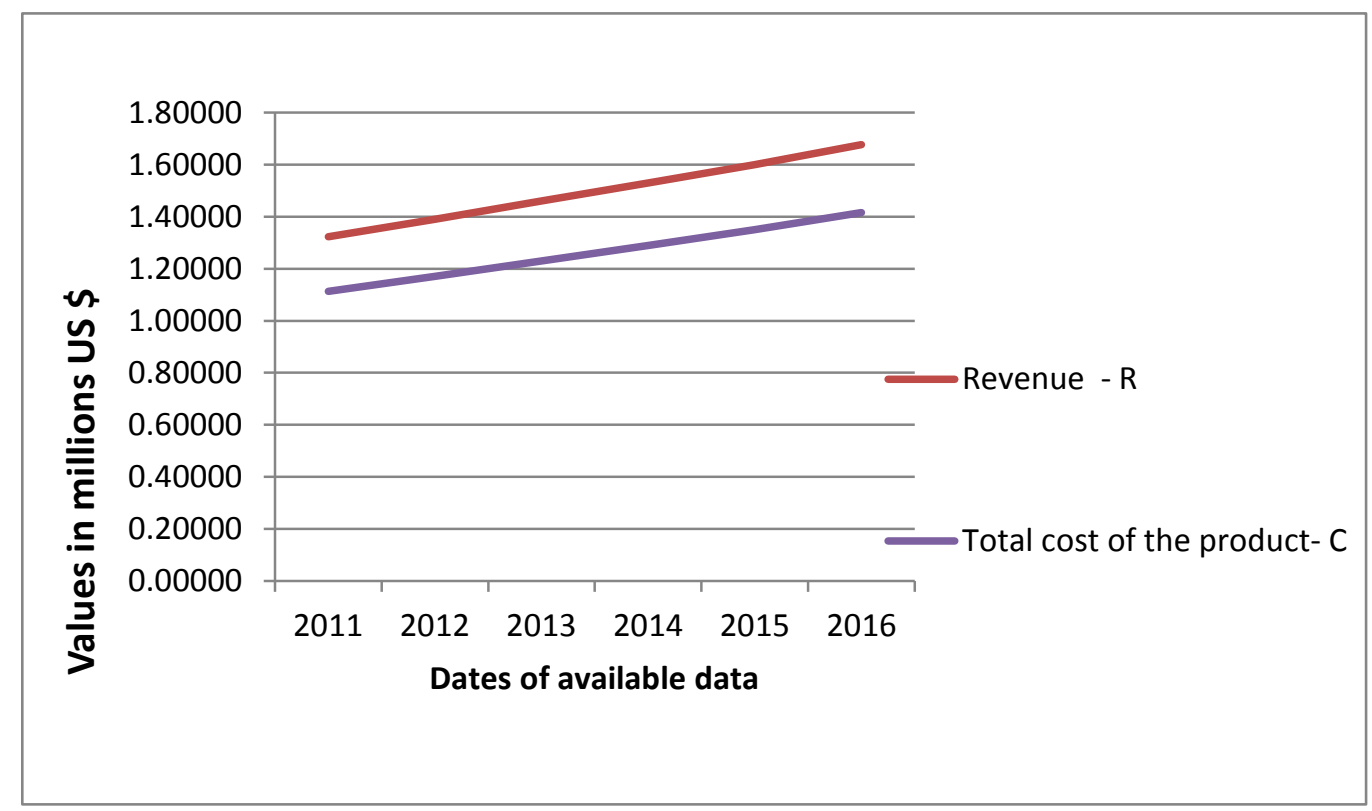

Figure 1. Taco Bell Revenue and Cost

\section{References} A $\begin{gathered}\text { website } \\ \text { https://www.numbeo.com/cost-of-living/country_result.jsp?country=Saudi+Arabia }\end{gathered}$
with

Brock, Horace R., Palmer, Charles E., Price, \& John Ellis. (1990). Accounting Principles and Applications $\left(6^{\text {th }}\right.$ ed.). Macmillan/McGraw-Hill, Missions Hills, California. 
Carl, L. Moore, Lane K. Anderson, \& Robert K. Jaedcke. (1988). Managerial Accounting. South-Western Publishing Company, Cincinnati, Ohio.

For stocks data check: www.amstock.com

Robert T. Clemen. (1996). Making Hard Decisions: An Introduction to Decision Analysis (2 ${ }^{\text {nd }}$ ed.). Wadsworth Publishing Company.

The Taco Bell is owned by YUM corporation, Taco Bell Data is found on YUM's franchise website. Retrieved from www.yumfranchises.com

The YUM released earnings. Retrieved from http://www.yum.com/app/uploads/Q2-2016-Final-Earnings-Release.pdf

Wholesale prices index methodology, Saudi Arabian General authority for statistics. Retrieved from www.stats.gov.sa

Zikmund G. Williams. (1994). Business Research Methods ( $4^{\text {th }}$ ed.). The Dryden Press, Harcourt Brace College Publishers, Fort Worth Texas.

\section{Notes}

Note 1. The businesses discussed in this paper are real, with imaginary names, although based on real businesses and similar facts and Tables. The author was not authorized to reveal data on these businesses, not to mention the actual names.

Note 2. This item was one of my lectures while teaching, as an adjunct professor at the Arab Open University, for which I wrote accounting statements and sheets, a few years ago; it was appropriate for a business on the university property.

Note 3. These business accounting sheets were done a few years ago. As an adjunct professor at the Arab Open University I used my memory of a rental car business in the US, the state of Minnesota 1983, where I rented a car for one week for $\$ 35, \$ 5$ per day. The owner, Jeffrey, whose name is all that I remember was so crooked he told me once done leave it where you last need it. It was a stolen car. Werdan is a gun runner, from al Natheem district in Riyadh, where I believe he owns a junkyard in the area. I met him on my way to Al Hafouf quite a few years ago, was not a good experience.

Note 4. YUM is the current owner of Taco Bell, along with many other franchises.

Note 5. The US Taco Bell data is given in Table 8.

Note 6. The prices were approximated from data given by Pilipino employees in the Taco Bell restaurants in Riyadh, requesting anonymity.

Note 7. Values from YUM's website and independent sources as mentioned above.

Note 8. The Taco Bell is owned by YUM corporation, available online www.yumfranchises.com ,Taco Bell data is found on YUM's website. For stocks data check: www.amstock.com 